\title{
RESEARCHPAPER
}

\section{A check list of blue green algae (Cyanobacteria) from the paddy field of Ranchi district (Jharkhand)}

\author{
Ashmrita Mahto \\ Department of Botany, Birsa College (R.U.), Khunti, Ranchi (Jharkhand) India \\ Email:Ashmritamahto@gmail.com
}

Article Info : Received : 16.02.2020; Revised : 11.03.2020; Accepted : 24.03.2020

The blue green algal flora found in the paddy field of Jharkhand is comparatively poorly known. Only few workers described the blue green algae principality growing in water habitats. In this investigation total 68 taxa of blue green algae belonging to 20 genera viz., Microcystis, Aphanothece, Aphanocapsa, Gloeothece, Gloeocapsa, Merismopedia, Synechococcus, Arthrospira, Oscillatoria, Phormidium Lyngbya, Nostoc, Anabaena, Anabaenopsis, Cylindrospermum, Aulosira, Calothrix, Gloeotrichia, Rivularia, Scytonema have been listed, identified, recorded first time from the various places of Ranchi district.

Key words : Blue, Green, Algae, Habitats

How to cite this paper : Mahto, Ashmrita (2020). A check list of blue green algae (Cyanobacteria) from the paddy field of Ranchi district (Jharkhand). Asian J. Bio. Sci., 15 (1) : 6-9. DOI : 10.15740/HAS/AJBS/15.1/6-9. Copyright@ 2020: Hind Agri-Horticultural Society. 